\title{
A questão das normas constitucionais sem juridicidade
}

\author{
The issue of constitutional norms without legality
}

\author{
Arnaldo Vasconcelos*
}

\section{Resumo}

Este artigo volta ao tema recorrente das normas de Direito Constitucional sem juridicidade, com o objetivo de negar toda consistência às teorias imperativistas que patrocinam tal entendimento. Seu núcleo epistemológico é, pois, o conceito metafísico de juridicidade, cuja abrangência repercute decididamente nas noções de liberdade, humanismo e democracia, com fundamento nas quais foram projetados os melhores modelos de teoria do Direito. Observase que, apesar das fortes refutações que têm sofrido as teses imperativistas, elas resistem quase incólumes. Entende-se que só a crença irracional numa ideologia pode sustentar o entendimento de que a estrutura fundamental do Direito consista numa relação de subordinação, e não de coordenação entre as pessoas, como pretende de modo dogmático o imperativismo jurídico.

Palavras-chave: Direito. Juridicidade. Bilateralidade-atributiva. Imperatividade. Humanismo e democracia.

\section{Abstract}

This article returns to the curring theme of rules of constitutional law without legality, with the aim of denying the consistency to imperativist as theories that spons or such understanding. Its epistemological core is therefore the metaphysical concept of legality, whose scope decided lyreflected in the notions of freedom, democracy and humanism, the basis of whicht he best models of theory of law were designed.We observe that, despite strong rebuttals that have suffered the imperativist as theses, they resist almost unscathed. It is

Mestre e Doutor em Direito. Licenciado em Filosofia. Professor titular do Programa de PósGraduação em Direito da Universidade de Fortaleza. Fortaleza - Ceará - Brasil. E-mail: arnaldo@ unifor.br 
understood that only the irrational belief in an ideology can sustain the view that the fundamental structure of law consistsin a relation of subordination, not coordination between people like want dogmatically legal imperative.

Keyword: Right. Legality. Bilateralism-attributive. Imperative. Humanism and democracy.

\section{Introdução}

A Escola Jurídica Normativista colheu expressivos resultados para o progresso da Filosofia e da Teoria do Direito, muito especialmente este alusivo à reformulação da teoria geral das fontes. Por sua decisiva influência, consumou-se o afastamento da aura de absolutismo imperial da lei escrita, à qual a Escola da Exegese havia deferido todo o espaço do jurídico, aos poucos e pouco vantajosamente ocupado pelo conceito multicompreensivo de norma jurídica. A lei, norma escrita e formal, manteve, contudo, sua posição originária de fonte prioritária e principal do Direito, por ter preservado a relevante função definitória das esferas da juridicidade: o legal, o lícito e o ilícito. Tal postura levou ao alargamento e à ampla valoração do campo jurídico da licitude, lugar onde a liberdade adquire condição especial para expandir-se ao compasso do progresso de uma nova hermenêutica humanista e democrática. A explicação última do sucesso colhido reside, induvidosamente, na configuração finalista da norma jurídica como um dever ser, sinal a apontar para o valor máximo da vida jurídica, qual seja, a realização da justiça. Donde a excelente definição de Direito como um dever-ser para ser justo, ponto do qual se descortina o mundo jurídico como reino dos valores.

Acontece, porém, que a marcha do conhecimento nunca é linear. Ao tempo em que disponibilizam grandes progressos, as inovações, elas mesmas, têm dado origem a novos problemas, alguns dos quais assumem a feição de extravagantes projeções. Bons exemplos disso podem ser colhidos nos desdobramentos das teorias dos normativistas e neo-normativistas. A começar pela versão do fundador e mais exitoso divulgador do movimento, o jurista austríaco Hans Kelsen. 
Do purismo absoluto, a partir do qual pretendeu Kelsen modelar seu conceito de Direito, apenas poderia resultar o modelo de um sistema jurídico tanto afastado de todo contexto histórico-social, como do compromisso com os valores fundamentais da liberdade. Quer dizer: projetou um normativismo em que as normas se fundam na exclusiva abstração do ato de pensar, em detrimento da complexa realidade fático-axiológica do mundo real, seu lugar de origem. A opção, confessa-o Kelsen (1997, p. 9) constrangido, representou para a ciência do Direito "una limitazione dolorosa della sua libertà di movimento". E, em razão disso, inevitável distorção, da qual resultou uma teoria jurídica sem Direito, pura sem pureza e científica sem cientificidade, consoante pretendo ter demonstrado em meu ensaio de repasse crítico da Teoria Pura do Direito (2010).

Não só em Kelsen, mas também em muitos autores que adotam, em maior ou menor extensão, o normativismo jurídico, os equívocos principais costumam situar-se em torno do par de categorias essência/ existência, com danos irreparáveis para a precisão e clareza de raciocínio. A fim de evitá-los, bastaria verificar-se a adequação entre essas categorias fundamentais e os respectivos campos do Direito, o jurídico sensível e o jurídico inteligível, considerados ambos em suas específicas determinações.

Outro motivo desse tipo de desvio epistemológico pode ser encontrado na confusão que se estabelece entre fundamento e legitimidade em sentido latu, figuras inteiramente diferentes e destinadas a resolver situações diversas. Através da legitimidade se pretende apurar se o poder governamental foi constituído ou se exerce de acordo com o respectivo sistema de legalidade. Deseja-se, na busca do fundamento, verificar qual o motivo da prescrição própria de cada norma ou dispositivo jurídico, para, através dele, apurar-lhe a aptidão de promover a justiça, medida configuradora do Direito em todos os trâmites de seu percurso.

Como fecho desses apontamentos introdutórios, falta colocar em pauta o tema da juridicidade, instância sede das questões pertinentes ao 
nosso assunto, qual seja, a possibilidade da existência, na Constituição, de normas ajurídicas. Dito com a abrangência necessária: de normas ou princípios sem juridicidade. Importa, desde logo, definir o que seja juridicidade. Em termos linguísticos, significa a qualidade ou caráter do ser jurídico, situando-se, assim, como primeira instância de validade do Direito. As outras três são a positividade, a vigência e a eficácia. qualificativo se aplica, em primeiro plano, à norma jurídica, instrumento próprio de manifestação do Direito abstrato, a saber, do Direito como modelo. E indica a aptidão do jurídico para estabelecer relações intersubjetivas das condutas humanas. De tal modo que, onde quer que se configure a intersubjetividade, aí há Direito. Nas palavras de Del Vecchio (1952, p. 58): "Qualquer proposição em que se verifique essa estrutura, isto é, se afirme uma tal relação intersubjetiva, tem incontestavelmente o caráter de Direito. A nota peculiar da bilateralidade jurídica consiste em que, para ambas as partes, A e B, existem direitos e obrigações correlatos e recíprocas. Nisso está precisamente a essência do Direito, nota que o distingue em relação às demais normas éticas e o individualiza como espécie autônoma, fixando-lhe a unicidade e permanência. Há de funcionar, portanto, em quaisquer circunstâncias de tempo e de lugar em que tenha ocorrido ou venha a ocorrer. Eis a razão decisiva pela qual toda visão do jurídico, que escape a essa perspectiva, atinge em cheio a liberdade do homem, maculando-lhe a dignidade.

Do exposto, ressalta que as conclusões mais firmes e valiosas, a serem extraídas do conceito de juridicidade, podem revestir as quatro formulações seguintes: $1^{a}$ - A juridicidade envolve a essência lógicoformal do Direito, sem pertinência a seu conteúdo histórico-axiológico; $2^{a}$ - O Direito é sistema de coordenação entre as partes, e não de subordinação de uma pela outra; 3- Ao gênero Direito pertence tanto o Direito Positivo, como o Natural; $4^{a}$ - a bilateralidade atributiva decorre da intersubjetividade ínsita na natureza do homem, a responder por sua condição primordial de ser que só alcança afirmar-se no reino da liberdade. 


\section{A teoria das normas programáticas e a insubsistência da concepção imperativista do Direito}

É chegado o momento de enfrentar as teses dos que afirmam a existência, nas constituições, de normas sem juridicidade. Parece oportuno iniciar o exame da matéria pela teoria das chamadas normas programáticas, que frequentou a preocupação dos juristas europeus e americanos por largo período. E embora se encontre ela em franco recuo, parece improvável que, em tempo previsível, seja afastada de vez. Mesmo levando-se em conta sua quase ou nenhuma consistência científica, tem a compreensivelmente sustentá-la a famosa teoria da imperatividade jurídica, indescartável, por vocações autoritárias, enquanto suporte ideológico do poder.

Através de nomes expressivos, quais os de Jean Dabin, de J. Haesaert, de Emílio Betti e o de Del Vecchio ainda positivista, entre muitos, postula a teoria que as normas constitucionais programáticas, a exemplo das enunciadoras dos Direitos Fundamentais, não têm juridicidade e nem, também, constitucionaliade. Isso porque Ihe faltaria conteúdo perceptivo (BETTI, 1971, p. 313), ou comando (DABIN, 1944, p. 45), ou ainda eficácia (HAESEART, 1948, p. 407), ou finalmente imperatividade (DEL VECCHIO, 1960, p. 319), termo esse que compreenderia todos os demais.

A presença de normas da espécie na Constituição teria valor meramente simbólico, tanto que não passavam elas de declarações políticas, afirmações doutrinárias ou proclamações ideológicas, por isso mesmo desprovidas de caráter vinculatório. O mesmo seria dizer que, por cumprirem apenas o objetivo de projetar os fins e as tarefas do Estado, não se destinariam à incidência, carecendo, pois, de aptidão para desencadearem, por si mesmas, o fenômeno da concreção jurídica. Portanto, a seu respeito não haveria de falar-se em eficácia normativa. Sua única finalidade seria inspirar o legislador, levando-o a exercer suas funções em consonância com o ideário nelas consubstanciado. Porém, não alcançariam, jamais, imporem-se ao juiz, em última instância pela razão decisiva de Ihes faltar conteúdo perceptivo ou comando. $\mathrm{O}$ 
entendimento de Del Vecchio (1960, p. 319), por fundado inteiramente na teoria da imperatividade, é exemplar da posição. Esse o motivo de o reproduzirmos em sua parte essencial:

Es un carácter importantíssimo y esencial de la norma jurídica, el de la imperatividad. [...] Ahora bien, imponer un deber significa precisamente imperar. Por conseguinte, aquello que es una simple afirmación u observación de hecho, no tiene carácter jurídico. El modo indicativo no existe para el Derecho. [...] También están fora en absoluto del campo del Derecho, los consejos y las simples exhortaciones. Tales enunciaciones - que no tienen naturaleza imperativa -. (Grifos do autor).

Está dito aí, de modo muito preciso e muito claro, que a essência do Direito, nota que o individualiza e o distingue das demais normas éticas, é a imperatividade. A norma que não for imperativa, embora integre o texto legal, jurídica não é. Depois disso, não se sabe como compatibilizar a noção de juridicidade, aí expressa, com esta outra, repetidamente apresentada por Del Vecchio (1957, p. 544; 1952, p. 58 e 369) em muitos de seus livros:

La juridicidad, por decirlo brevemente, consiste en aquella determinación bilateral (intersubjetiva) del obrar, por la cual a la facultad de un sujeto corresponde la obligación de outro; y esta forma lógica no comprende en absoluto, si bien se mira, em requisito de la positividad.

Note-se que, agora, Del Vecchio (1957) já não fala em impor deveres, o que significaria o mesmo que imperar. Refere-se, antes, à correlação entre faculdades e obrigações, potencialidades implícitas na determinação bilateral do agir. A fim de afastar dúvidas, Del Vecchio (1957) apressa-se em excluir da juridicidade a positividade. Com efeito, se a essência do Direito, ou juridicidade, constitui mera forma lógica, ela existe independentemente de positivação. Nada de original aqui, apenas a reafirmação da doutrina metafísica tradicional de que a essência precede à existência e diante dela guarda completa autonomia. Cabe, pois, concluir: se a essência não compreende o requisito da positividade, 
também não envolve, por consequência, o da imperatividade, posto que aquela é precondição desta. Se assim é, como parece fora de dúvida, a afirmação inicial de Del Vecchio (1957), segundo a qual a essência do Direito consiste na imperatividade, fica inteiramente desfeita por suas próprias e incisivas palavras.

Pode-se afirmar, com segurança, que é esta última a posição decisiva de Del Vecchio a respeito da natureza do Direito. Visualizando a conduta jurídica a partir da liberdade humana, segundo sábias lições de seu mestre Immanuel Kant, não podia o jusfilósofo italiano figurar as partes da relação jurídica no plano imperativo da subordinação, mas somente no plano indicativo da coordenação. No primeiro, apenas se reconhece a desigualdade natural entre os homens, enquanto no segundo, partindo dessa mesma evidência, busca-se torná-los iguais em dignidade perante o Direito. Sobressai, assim, a função civilizatória que a vida jurídica tem desempenhado no processo de igualação e humanização do homem. Este deve ser o propósito de toda teoria do Direito humanista e democrática, como se nos afigura o último pensamento de Del Vecchio. Outro pequeno texto de sua autoria confirma esse entendimento:

[...] aquello que contituye propiamente el Derecho. Nosotros entendemos la esencia de este concepto como la relación intersubjetiva o bilateral, o sea la cordinación de situaciones de varios sujetos, por la cual uno de ellos puede pretender alguna cosa [...] a la que el otro está obligado. (DEL VECCHIO, 1957, p. 372-373).

Ressalte-se, por fim, que a afirmação da existência de normas legais desprovidas de juridicidade conduz a uma teoria hoje inteiramente superada, a saber, aquela que proclama a necessária lacunosidade do Direito. Lacunosa pode ser a lei. O Direito, não. Isso é o que se deve afirmar com inteira segurança em face da inserção formal, nos ordenamentos jurídicos contemporâneos, do princípio da licitude, segundo o qual é jurídica, porque lícita, toda ação que não contravenha obrigação legal de índole positiva ou negativa (Constituição Federal, art. $5^{\circ}$, inc. II). Existe, pois, plena coincidência entre juridicidade e 
socialidade. Não há, na vida social, nenhum ato, por insignificante que possa parecer, capaz de subtrair-se ao domínio do Direito. A mesma Constituição Federal o prescreve, ao incluir, no título relativo aos Direitos e Garantias Fundamentais, dispositivo segundo o qual "a lei não excluirá da apreciação do Poder Judiciário lesão ou ameaça a direito” (CF, art. $5^{\circ}$, inc. $\left.X X X V\right)$.

Já vai bem distante o tempo em que se poderia afirmar, com Francesco Carnelutti, entre outros, que nas relações sociais existiam, ao lado de ações que interessavam ao Direito, outras que absolutamente a ele não diziam respeito. As primeiras tinham juridicidade. As segundas, não. Pretendia-se, ao que parece, compatibilizar o postulado políticoliberal do mínimo de Estado com seu natural correspondente jurídico, o mínimo de Direito. A exata concordância entre os domínios da lei e do Direito, estabelecida pelo positivismo da Escola da Exegese, propiciou o fundamento da teoria.

\section{Definição essencial do Direito: compartição de liberdade}

Tudo devidamente considerado, tem-se que é a bilateralidade atributiva, o ter-que-ser-para-o-outro ou alteridade, a nota constitutiva do jurídico. Sabe-se o que significa bilateralidade atributiva, sendo fácil recordá-lo. Consiste na capacidade ou aptidão para estabelecer relações atributivas, assim ditas porque delas decorrem direitos e obrigações correlatos e recíprocos. Evidencia-se a característica da proporcionalidade, procedente do fato primordial de ser o Direito compartição de liberdade.

Com efeito, a questão da origem do Direito e do Estado, tornada preocupação central dos contratualistas, foi esta: como possibilitar o exercício social das liberdades, tendo-se em conta que, por definição, a liberdade natural de cada um é ilimitada? A resposta apontou para a solução consistente na invenção do Direito como instrumento capaz de garantir, através da equânime limitação da liberdade de cada um, o máximo de liberdade possível para uso individual e social. A limitação 
não representou prejuízo nenhum, porém todo o lucro possível. Simplesmente porque, como advertiu Thomas Hobbes (s./d., p. 102), "o direito de todos os homens a todas as coisas não vale de fato mais do que se alguém não tivesse direito a nada".

Se o Direito é compartição de liberdade, não pode fazer-se representar por conceito que indica imperatividade/subordinação. Seu modo de ser peculiar é a bilateralidade/coordenação. $E$ isso não envolve assunto que só se possa entender com a ajuda da filosofia e da ciência. Até os poetas, metafísicos intuitivos que são, sabem muito bem disso. Comprova-o a expressiva síntese de Dante Alighiere (1983, p. 58): “O direito é uma proporção real e pessoal de homem para homem, a qual, se observada, serve a sociedade, e se contrariada, a corrompe".

Por conseguinte, a nota da bilateralidade-atributiva, intersubjetividade ou expressão equivalente, constitui a essência do Direito, ou juridicidade, dado que o individualiza e o distingue de modo permanente, revelando-lhe assim a natureza. E como, inclusive, nada pode ter duas essências, afaste-se em definitivo da definição do Direito a noção de imperatividade. Ou de qualquer outro duplo, a exemplo da coação.

Se bem se observa, dá para notar que a maioria dos imperativistas partilha o equívoco da dupla essência do Direito, imperatividade/ subordinação e bilateralidade/coordenação, embora, por natureza, sejam em si mesmas lógica e ontologicamente excludentes. Georg Jellinek, embora integrado a essa linha de pensamento, pretendeu livrar-se do problema através do apelo à clássica distinção entre Direito Público e Direito Privado, caracterizando este como coordenativo e aquele como subordinativo das ações humanas. A emenda só fez agravá-lo, ao contribuir para ampliar a confusão entre os níveis epistemológicos do metafísico/inteligível e do físico/sensível, entre os planos da essência e da existência, entre as ordens do ser e do dever ser.

Relativamente à dicotomia ser e dever ser, não se pode predicar-lhe redutibilidade, nem tampouco incomunicabilidade, como persistentemente o tentou Kelsen sem sucesso. De outra parte, 
admitida por hipótese a possibilidade de coincidência, o fenômeno do conhecimento tornar-se-ia impraticável, de tal modo a dinâmica que envolve os termos da distinção é fundamental para o desempenho de suas funções epistemológicas.

$\mathrm{Na}$ verdade, ser e dever ser constituem as duas faces do real, entidade dupla, um princípio e modelo da outra. Ao ser absoluto e uno, contrapõe-se o dever ser relativo e múltiplo, como ocorre, por exemplo, com o conceito universal de Direito e suas diversas caracterizações regionais. Sendo o mundo do dever ser existencial ou fenomenológico, portanto lugar das relatividades e das multiplicidades, fica evidente que é aí, precisamente, onde podem ocorrer descaracterizações e distorções. Tal acontece todas as vezes em que o dever ser não se realiza por participação no ser. Exatamente o que se verifica nas definições do Direito em termos de imperativo ou coação, porquanto nenhuma dessas notas participa da ideia essencial da juridicidade como bilateraliadeatributiva.

A anterioridade da essência sobre a existência corresponde, em linha direta, à precedência da juridicidade sobre a positividade, vale dizer, da qualidade sobre a quantidade. O caminho é único: primeiro a ideia do Direito, depois a norma correspondente, que a positiva. Se há filosofias da qualidade e filosofias da quantidade, às primeiras pertence a tarefa de elaboração do conceito ontológico do Direito.

Como se sabe, o Direito não é um ser autônomo (substância, sujeito ou coisa), mas um ser de dependência (acidente, atributo ou qualidade). Não é ele a conduta, mas apenas aquela que se juridicizou pela incidência normativa: a conduta jurídica (Carlos Cossio). Ao qualificar o ser-substância (conduta), o ser-acidente (jurídica) o determina, tornado-o prioritário por sua transcendência: há condutas direitas, porque existe o Direito, assim como há coisas belas porque existe a beleza.

Funda-se o Direito, portanto, numa qualidade ou valor, a bilateraliade-atributiva, pela qual se faz representar o sistema de compartição ou coordenação de liberdades, que o consubstancia. E, 
tendo em vista a bipolaridade dos valores, o essencial nexo coordenativo do Direito afasta a ideia de subordinação ínsita à imperatividade, assim como o valor afasta o desvalor.

Até aqui se examinou, através de diversas perspectivas epistemológicas, em que consiste a juridicidade e como e por quais razão é ela decididamente incompatível com a noção de imperativo ou comando. Caberia, de resto, aos imperativistas, enfrentando os argumentos que lhes são antepostos, dizer em que de fato consiste sua teoria e como efetivamente funciona. Inclusive esclarecer o seguinte ponto, por demais sensível: tendo em vista o princípio lógico da transmissão da essência do gênero às respectivas espécies, como explicar a coexistência, numa mesmo domínio jurídico, - o constitucional, por exemplo, - de normas imperativas e não imperativas. Vale dizer, de normas jurídicas e não jurídicas. E noutro plano, o da eficácia, que peculiaridade marcaria as normas de Direito Penal, induvidosamente tidas por imperativas? Em razão disso, poderá a teoria sustentar o entendimento de que quem mata é punido, quando todos sabemos que há tantos inocentes encarcerados como criminosos livres. Não seria desolador verificar quanto de crueldade habita esse imperativo penal, tanto que parece comprazer-se em abarrotar os presídios com pobres, pretos e analfabetos, deixando quase sistematicamente fora deles ricos, brancos e letrados? E mais, muito mais.

De todo modo, se há quem detenha resposta capaz de escusar a teoria da imperatividade, prestaria grande serviço à ciência jurídica, divulgando-a para conhecimento geral. Toda tentativa nesse sentido seria desejável. Antes, pelo contrário, os defensores da teoria, ao tentarem dissimular seu conteúdo sob as mais insólitas qualificações, parecem contentar-se em propor emendas a enfrentar abertamente a questão principal. Nesse sentido, afirma-se da norma jurídica que ela é um imperativo hipotético (Léon Duguit), um imperativo independente (Karl Olivecrona), um imperativo atributivo (Léon Petrasizky), um mandato tácito (John Austin), um mandato anônimo (Luigi Ferri), um comando impessoal (H. G. Bohnert), um imperativo condicionado (Giuseppe Lumia), um mandato impessoal (Karl Engisch), um imperativo 
despsicologizado (Hans Kelsen), um imperativo autorizante (Goffredo Telles Júnior) ou, ainda, um imperativo indicativo (Cláudio Souto).

Pela extensão do elenco das adjetivações, tem-se a impressão de que, para seus adeptos, presta-se a imperatividade a qualquer adaptação, embora não se sintam encorajados a demonstrar sua serventia prática ou consistência científica. Reforma-se apenas para tentar assegurar a permanência da teoria, conservando intacto seu núcleo de índole autoritária, que repousa no extravagante entendimento da essência do Direito em termos de ordem, comando ou imperativo. Em suma: o Direito como acatamento da desigualdade, representado pela ordem do soberano ao súdito, consoante termos da clássica formulação hobbesiana. Exatamente o contrário do que deve ser ele numa sociedade de homens livres. Essas restrições todas, na verdade, constituem um bom motivo para seus defensores permaneçam ancorados na presumível autossuficiência da postura dogmática, que é fechada e sectária. O reforço ideológico, que a tem acompanhado desde sempre, reforça seu círculo de proteção e incolumidade.

\section{Ideologia e fatores reais do poder}

Regra geral, a ideologia dos juristas desempenha, relativamente aos fatores reais de poder de cada sociedade (LASSALE,1969), o papel conservador de manutenção das estruturas e instituições sociais. Para que assim seja, faz-se necessário controlar os usos do poder, a fim de que não ultrapassem os limites consentidos. Bons instrumentos para tal objetivo sempre foram encontrados com facilidade na área do Direito, nas leis e doutrinas jurídicas em primeiro lugar. Sendo a Constituição a Lei responsável pela eticidade e unidade da vida jurídica, é aí que as inovações devem ser acolhidas, a fim de que possam gozar plenamente de seu caráter de fundamentalidade. Tudo se resume na simbologia da norma constitucional. É no momento de invocação dessa norma que se recorre, contra sua validade, ao dispositivo da reserva ideológica, pronto em identificar ausência de imperatividade no preceito constitucional. 
A partir desse ponto, passou a afirmar-se que a norma constitucional sem imperatividade, por não ser jurídica, tem apenas caráter programático, devendo, portanto, negar-se-lhe aplicabilidade. Em resumo: normas com esse caráter não são vinculatórias.

Em ensaio dedicado especialmente da aplicabilidade dessas normas, José Afonso da Silva (1998, p. 153) pôde captar, com precisão, a tática ideológica subjacente à teoria da imperatividade. São palavras suas:

\begin{abstract}
Essa tese, hoje combatida seriamente, é responsável pela caracterização, como programática, de toda norma constitucional incômoda. É fácil, realmente, descartar-se da incidência de uma regra, bastando tachá-la de programática e, assim, nos termos de tal doutrina, o princípio seria posto de lado.
\end{abstract}

A rigor, todas as versões da teoria da imperatividade, atraentes como possam ser a seus adeptos, abrigam perversa contradição, a saber: se, de um lado, pretendem reforçar a garantia de aplicabilidade da norma jurídica, em nome da segurança do Direito, um de seus valores fundamentais, por outro lado, ao proclamarem a coexistência de normas imperativas (jurídicas) e não imperativas (ajurídicas) nos códigos e nas leis, aquelas vinculantes e essas não vinculantes, levam à insegurança e ao descrédito do Direito. O resultado é francamente adverso, pois enquanto a segurança prometida pela teoria é de todo ilusória, a insegurança decorrente de negação da aplicabilidade é, ao contrário, real e funesta.

\title{
4 Posição dos juristas brasileiros sobre a existência de normas constitucionais sem juridicidade
}

Contudo, há de registrar-se que a grande maioria dos constitucionalistas brasileiros rejeita a extensão da teoria da imperatividade às normas constitucionais. E nessa posição se colocam, com tal firmeza, que as pouquíssimas vozes destoantes, em geral advindas de doutrinariamente pouco avisados, perdem-se por falta de 
ressonância. Tome-se, como exemplo da melhor doutrina constitucional, o que, na obra "A Constituição Aberta”, escreveu a propósito Paulo Bonavides (1993, p. 142):

Desde muito direitos fundamentais de teor igualitário deixaram de ocupar nas Constituições o lugar abstrato das declarações programáticas. [...] Tudo que está na Constituição é jurídico, eis a assertiva que cumpriria fazer se precisássemos de semelhante truísmo para mostrar quer o instrumento constitucional não é um texto de literatura política, mas a lei das leis, o código dos códigos na organização jurídica que fundamenta uma sociedade. (Grifos nossos).

Como se nota, é indisfarçável o sentimento de repúdio de Paulo Bonavides à teoria negativista de juridicidade aos direitos e garantias fundamentais do homem. E com toda razão. Não representaria imenso despropósito admitir, a par de tal teoria, a opinião comum de autores, segundo a qual, relativamente ao aspecto particular da juridicidade, nenhuma diferença existe entre o estatuto da Máfia e as normas da Constituição inglesa ou do Código Civil francês, por exemplo? Entretanto, a Teoria do Direito sempre assim o ensinou de modo claro e franco, através de vozes autorizadas em todos os tempos, entre as quais se podem relacionar Platão, Cícero, Santo Agostinho, August Thon, Ihering, Santi Romano, Giuseppe Maggiore, Louis Le Fur, Cesarini Sforza, Max Ernst Mayer e Hans Kelsen. E, entre os não juristas, ao que me lembre no momento, Voltaire e Benedetto Croce. Confira-se em minha "Teoria da norma jurídica" (VASCONCELOS, 2006, p. 251-255). É de observar que, entre os autores citados, encontram-se precisamente alguns defensores da teoria imperativista. Tudo bem ponderado, ter-se-ia que, enquanto é afirmada a juridicidade do estatuto da Máfia, a das normas constitucionais programáticas seria liminarmente negada.

Tamanho radicalismo parece só encontrar paralelo na teoria jusnaturalista de conformação teológica, para a qual Direito injusto não é Direito. Seria o que, então? Por ironia, a indagação encontra resposta satisfatória justamente em um dos mais severos patrocinadores da teoria, 
Santo Tomás de Aquino. As coisas, ensina o patrono das universidades, existem de dois modos: conforme sua natureza ou como deturpação dela. Se assim ocorre, como parece certíssimo, Direito injusto é Direito. Direito deturpado, é certo, mas de todo modo Direito.

Colocada a questão, por fim, à luz da teoria das instâncias de validade jurídica, comprovar-se-á, mais uma vez, a inconsistência da assertiva de que existem na Constituição normas sem juridicidade. Como toda norma, a constitucional possui, em ordem inicial de formação, juridicidade e positividade. Juridicidade, pela única e simples circunstância de ostentar aptidão para estabelecer relações bilateraisatributivas. E positividade, tão só por terem sido postas por ato de legislador competente. Entretanto, das quatro instâncias de validade, as duas referidas e mais a vigência e a eficácia, é a juridicidade a única que guarda plena autonomia existencial, A norma é jurídica em si e por si. Não está na vontade do legislador atribuir-lhe ou dela retirar essa nota essencial. Ela pré-existe como fato jurígeno. Esse princípio da autonomia da juridicidade é tão fundamental e decisivo, que Rudolf Stammler (1929, p. 466) nele centrou sua excelente definição de Direito como "querer vinculatório, autárquico e inviolável".

A juridicidade, pois, existe independentemente da positividade, tanto considerada em nível constitucional, como infraconstitucional. Não parece supérfluo repetir: não é a Constituição, muito menos a lei, que transmite juridicidade ao preceito normativo. Vem a propósito lembrar a sábia lição de Paulo, na tradução de R. Limongi França (1969, p. 48), segundo a qual "não é da regra que promana o direito, senão com base no direito, existente por si mesmo, que a regra é elaborada". (Grifos nossos). No original: "Non ut ex regula jus sumatur, sed ex jure, quod est, regula fiat".

Todos os argumentos contrapostos à teoria da não juridicidade das normas constitucionais, especialmente os de feição programática, por consistentes e numerosas que sejam, não deverão, contudo, encerrar a disputa em tempo previsível, dada principalmente a ideologização do tema. No entanto, faz-se necessário persistir no esforço para invalidar, desde seu fundamento, a teoria da imperatividade do Direito. 
Segundo a ordem natural das coisas, por dois diversos caminhos deveria a tarefa ser conduzida: o ataque frontal ao subterfúgio ideológico no qual a teoria buscou proteger-se e o posicionamento do debate em seu nível epistemológico próprio, que é o domínio da ontologia. Como nenhum dos dois atrai os chamados operadores do Direito, geralmente circunscritos ao espaço positivista, limitado e infértil, optou-se por uma terceira via, essa de índole retórico-pragmática. Tudo de modo muito semelhante ao que ocorre com a teoria da norma como coação.

Houve entre nós uma outra alternativa, de caráter nitidamente político, a qual consistiu em condescender com a teoria da imperatividade, adaptando-a, porém, ao ideário republicano e liberal, através de decisivo redirecionamento de seu significado histórico. Esta foi a solução adotada por Rui Barbosa (1933, v. II, p. 489) em passagem incisiva dos comentários a nossa primeira Constituição republicana, da qual foi um dos principais artífices. Vale por uma nova teoria, merecendo, a nosso juízo, ter sido melhor apreciada pelos estudiosos do Direito Constitucional brasileiro. O texto referido é este: "Não há, numa Constituição, cláusula a que se deva atribuir meramente o valor de conselhos, avisos ou lições. Todas têm força imperativa de regras ditadas pela soberania nacional ou popular aos seus órgãos"..

Sendo a Constituição a norma fundamentadora de cada ordenamento jurídico, entende-se que a fórmula doutrinária aí contida tem aplicação ao Direito por inteiro, não se limitando, pois, ao âmbito restrito da norma constitucional. De outro modo, também não se poderia postular o princípio do domínio da soberania sobre toda a nação. Aliás, expressamente invocado por Rui, como ponto de apoio, no próprio enunciado da tese que construiu.

Outra posição digna de registro, por sua singularidade, é a de Meirelles Teixeira (1991), Professor de Direito Constitucional da Faculdade Paulista de Direito da Universidade Católica de São Paulo, aí pelos meados do século passado. No seu entender, a questão sob exame se põe a partir do confronto entre normas jurídicas, mas não positivas, preexistentes à Constituição, - a exemplo dos grandes 
princípios do Direito Natural, da justiça, da democracia e daqueles pertencentes ao Direito nacional e internacional - e a Constituição sem juridicidade, resultante da não observância desses princípios pelo poder constituinte. (Grifamos). Nas suas palavras:

Em relação a esses princípios não positivos, mas jurídicos, num sentido superior e mais elevado ainda, aos quais o Poder Constituinte está subordinado, pode-se falar em juridicidade da constituição. Não seria jurídica, nesse sentido amplo, uma constituição que não observasse tais princípios. (TEIXEIRA, 1991, p. 222). Grifos do autor.

É de ver-se que esses, relacionados por Meirelles Teixeira, são, em sua totalidade, genuínos princípios do Direito Natural moderno, inspiradores das grandes revoluções liberais-democráticas norteamericana e francesa. Em síntese: Constituição ajurídica seria aquela que não teve por modelo os princípios superiores do Direito natural.

Sem muito esforço, dá para identificar, desde logo, o desvio de perspectiva ocorrido na colocação do problema, fatal para seu deslinde. Tomou-se o plano da fundamentação do jurídico, lugar onde se busca mensurar-lhe o valor de justiça, pelo plano da simples aferição da juridicidade, ocasião em que apenas se cuida da aptidão desta para formar relações bilaterais atributivas da conduta humana. A juridicidade é instancia meramente formal. Aponta para o que é Direito, independentemente de valoração positiva ou negativa. A justiça, a partir do Direito constituído, tem a humana pretensão de fazer prevalecer, na apuração desse Direito positivado, os princípios supraconstitucionais do Direito Natural. Ao ressalvar a inadequação do uso que deles se fez, empregando-os na busca de normas constitucionais sem juridicidade, desejo, contudo, juntar-me ao Professor Meirelles Teixeira para proclamar a insubstituível propriedade dos referidos princípios gerais para fertilizar cotidianamente o Direito Positivo. Daí o crescente interesse que têm despertado, nos tempos atuais, em sua versão constitucional de Direitos Fundamentais. 
Outros muitos juristas se têm pronunciado sobre ambas as faces da questão, a saber, a existência ou a inexistência de normas constitucionais sem juridicidade. Vêm-me à memória os nomes de dois outros brasileiros contemporâneos, os quais, em obras publicadas, perfilham decididamente a opinião de que toda norma constitucional é dotada de juridicidade. Cito-os pela ordem de edição de seus livros. Paulo Roberto Lyrio Pimenta (1991), Juiz Federal e Professor da Faculdade de Direito de Salvador, em sua tese de mestrado intitulada "Eficácia e Aplicabilidade das Normas Constitucionais Programáticas". Aí, após posicionar-se no sentido de que "a norma constitucional é uma norma jurídica que apresenta os mesmos caracteres e propriedades das demais", acrescenta, justificando-se à maneira dialética:

[...] devendo-se rejeitar, pois, a concepção doutrinária que sustenta opinião contrária, a qual, todavia, não se compatibiliza com o conceito (de) Constituição outrora mencionado, eis que parte de distinção, já superada, entre direito constitucional material e direito constitucional formal. (PIMENTA, 1999, p. 87).

O outro jurista referido acima é o Ministro aposentado do Supremo Tribunal Federal, Carlos Ayres Brito (2003), com destacada passagem pelo magistério da Universidade Federal de Sergipe. Sua posição a respeito do assunto pode ser colhida na obra "Teoria da Constituição", onde se lê, na parte relativa "à eficácia máxima da Constituição como principal diretriz hermenêutica", a proposição segundo a qual, "sendo toda norma constitucional uma norma jurídica, existe, em última análise para cumprir uma função técnica de controle social” (BRITO, 2003, p. 198. Grifamos).

Tamanha concisão talvez possa ser creditada a pouca ou nenhuma importância que comumente se atribuiu à opinião contrária, demais, minoritária entre nós. Isso, devido sobretudo a seu caráter conservador. Donde o propósito de renovação, nutrido dos sentimentos de inspiração humanista e democrática, que presidiram a elaboração da Carta Magna de 1988. Tanto assim que mereceu ela, de um de seus maiores idealizadores, Deputado Ulisses Guimarães, a denominação 
fortemente simbólica de Constituição Cidadã. Tudo compreendido no valor síntese que empresta fundamento à existência da República brasileira: a dignidade da pessoa humana (CF, art. $1^{\circ}$, inc. III).

\section{Tratamento da matéria na Constituição vigente}

Com relação ao tema, a Constituição o manteve sob a égide dos Direitos e Garantias Fundamentais (Tít. I), com espaços distintos para os Direito e Deveres Individuais e Coletivos (Cap. I) e para os Direitos Sociais (Cap. II), dispensando-Ihes tratamento diferenciado de acordo com o caráter próprio de cada um desses conjuntos.

E foi, de fato, o que se verificou. Situou-se no campo específico dos Direitos e Deveres Individuais e Coletivos - distribuídos num só artigo, o $5^{\circ}$ - preceitos de abrangência genérica, os quais, por motivos de ordem lógica impostergáveis deveriam integrar a área normativa dos Direitos e Garantias Fundamentais. Confira-se pela leitura dos parágrafos $1^{\circ}$ e $2^{\circ}$ do artigo $5^{\circ}$, a seguir reproduzidos:

$\S 1^{\circ}$ As normas definidoras dos direitos e garantias fundamentais têm aplicação imediata.

$\S 2^{\circ}$ Os direitos e garantias expressos nesta Constituição não excluem outros decorrentes do regime e dos princípios por ela adotados, ou dos tratados internacionais em que a República Federativa do Brasil seja parte. Grifamos.

Como ficou estruturado o Título I, caberia perfeitamente indagar se, do ponto de vista da Lógica Jurídica, as disposições desse parágrafo $1^{\circ}$ se estenderiam aos Direitos Sociais (Cap. II, arts. $6^{\circ}$ ao $9^{\circ}$ ), tendo em vista que, pelo princípio clássico de transmissão das essências, apenas as do gênero passariam às respectivas espécies, vedada a circulação das essências das espécies entre si. Isso posto, a resposta seria negativa: os dispositivos referentes aos Direitos Sociais não teriam aplicação imediata, por isso automaticamente incluídos na categoria das normas constitucionais programáticas. Nada obstante, o legislador constituinte entendera de maneira diversa, destacando do conjunto 
aquelas que estariam a carecer de leis regulamentadoras. São em número de doze, a saber: Art. $7^{\circ}$, incs. I, X, XI, XIX, XX, XXI e XXII; Art. $8^{\circ}$, incs. I, VIII e VIII, parág. único; e Art. $9^{\circ}$, parágrafos. $1^{\circ}$ e $2^{\circ}$. Tudo ponderado, tem-se que, no texto constitucional sobre Direitos sociais, como em qualquer corpo de leis, poderiam coexistir normas de duas ordens: as autônomas, de aplicação imediata, e por isso jurídicas, e as programáticas, dependentes de regulamentação posterior, como tais ajurídicas.

Em razão de ter-se especializado no estudo da matéria entre nós, destaco aqui a posição doutrinária de José Afonso da Silva (1993), especialmente no que concerne às normas constitucionais programáticas, para ele normas jurídicas na inteira significação do termo. As diferenças, que as distinguem, em nada interferem na essencial juridicidade delas. Em seu entender, pois,

[...] as (normas), que definem os direitos econômicos e sociais, [...] especialmente as que mencionam uma lei integradora, são de eficácia limitada, de princípios programáticos e de aplicação indireta, mas são tão jurídicas como as outras... (SILVA, 1993, p. 165. Grifos nossos).

Faria falta, em estudo que envolve a aplicabilidade das normas programáticas, omitir a posição do Poder Judiciário em sua instância definitiva e irrecorrível, o Supremo Tribunal Federal. Tem-se firmado nessa Corte, com apoio em precedente de seu decano, Ministro Celso de Mello, o entendimento de que, em face de patente omissão da autoridade pública, o Poder Judiciário deve suprir a intolerável lacuna. Com efeito, em 22/12/2006, na qualidade de relator do Agravo Regimental no Recurso Extraordinário 393.175-0, originário Rio Grande do Sul, teve ocasião de afirmar que "a interpretação da norma programática não pode transformá-la em promessa constitucional inconsequente." (grifos do original). É tudo, em tão poucas palavras. As quais, bem interpretadas sob a superior perspectiva da finalidade do Direito, valem por uma teoria. 
Dando remate a esse ponto de indiscutível significado para a credibilidade da ordem jurídica nacional, não se pode deixar de colocar em evidência o fato de que tanto os Direitos individuais como os Direitos coletivos encontram-se formalmente garantidos pela figura processual do mandado de injunção, consoante o disposto no item LXXI, do artigo $5^{\circ}$, da Constituição Federal, do seguinte teor: "Conceder-se-á mandado de injunção sempre que a falta de norma regulamentadora torne inviável o exercício dos direitos e liberdades constitucionais e das prerrogativas inerentes à nacionalidade, à soberania e à cidadania." Cumpre, então, vigiar no sentido de mantê-lo atuante, exercitando-o sempre que necessário.

Como esse artigo situa-se fundamentalmente em torno de dois polos de índole metafísica, as definições de juridicidade e de imperatividade, não quero encerrá-lo sem recomendar a leitura da crítica fenomenológica do imperativismo jurídico produzida por Giorgio Balladore Pallieri (1969, v.II, p. 12-26) e Carlos Cossio (1954, p. 144150). São textos extraordinários, dignos de serem sempre revisitados, para que se evite, tanto quanto possível, as superficialidades inerentes às visões positivistas.

\section{Conclusão}

A pesquisa e elaboração desse trabalho conduziram às seguintes conclusões principais:

$1^{\text {a }}$ A teoria que aponta para a existência de normas constitucionais sem juridicidade é típica do pensamento positivista de todos os tempos, o qual sempre se fez apoiar na falsa concepção de que o Direito é, por natureza, ordem, comando ou imperativo. Em síntese: relação de subordinação entre as pessoas. Os regimes autoritários, monárquicos ou republicanos, sempre encontraram nessa teoria um instrumento hábil com o qual incrementar suas políticas reacionárias e discriminatórias.

$2^{a}$ Ao assumirem essa posição de ordem político-ideológica, os juristas que a perfilharam fizeram por ignorar a referência primordial 
do ente jurídico, a nota que o individualiza e o distingue de modo permanente. Trata-se de sua essência como estrutura bilateral atributiva da conduta humana, com aptidão para estabelecer relações de coordenação objetivando o partilhamento da liberdade entre as pessoas. A lição é fatal: a liberdade à custa da autonomia do outro é insegurança, precisamente o contrário daquilo a que se propõe o Direito como propensão axiológica.

$3^{\circ}$ Nada obstante, o positivismo persistia em enfrentar a questão da segurança jurídica, órfã dos cuidados divinos desde fins da Idade Média, com as teorias da imperatividade e da coação, defendidas pelos grandes juristas europeus especialmente no século XIX. Ainda no século passado, seu mais eminente jurista, Hans Kelsen, adota tanto a teoria da coação, como a de um extravagante imperativo despsicologizado com idêntico propósito. Ao que se observava, ninguém sabia ao certo o que diziam seus defensores e como realmente elas funcionavam, mas nunca se interpunham essas indagações, por politicamente inoportunas. Temia-se ter de trocar as certezas dos códigos pelas dúvidas da metafísica. Na verdade, o caso era antes de pouca ciência e muita retórica pseudorrealista. A exemplo do mesmo Kelsen, o qual empenhou toda a sua existência na construção de uma teoria do direito sem Direito.

$4^{a}$ Por diversos meios foram ensaiadas teorias para recusar juridicidade a certas espécies de normas constitucionais. O tipo preferencialmente visado foi o das denominadas normas programáticas, assim tidas por carentes de eficácia imediata, donde lhes era negada aplicabilidade. Exemplo clássico, entre nós, foi o relativo ao Direito de greve, abrigado pela Constituição de 1946. A Constituição atual mudou para melhor relativamente aos Direitos individuais e coletivos, não assim no que concerne aos Direitos sociais. Contudo, tem-se firmado no Supremo Tribunal Federal o entendimento de que o princípio da inaplicabilidade das normas programáticas não pode ser tido por absoluto, a ponto de prestar-se ao acobertamento de danosa omissão do poder regulamentar. A fim de obviá-la, deve o Judiciário suprir a intolerável lacuna. 
$5^{a}$ Ressalte-se, por derradeiro, que a teoria da existência de normas constitucionais ajurídicas nunca exerceu domínio absoluto dado o confronto que lhe opuseram, a nível doutrinário, as teorias do Direito Natural e do Direito Social, na luta solidária em favor do uso político da igualdade como princípio de igualação jurídica entre os indivíduos e entre as classes sociais. Não foi tudo, mas foi decisivo na formação da consciência cidadã.

\section{Referências}

ALIGHIERI, Dante. Monarquia. Tradução de Hernâni Donato. São Paulo: Parma, 1983.

BETTI, Emílio. Interpretazione della legge e degli atti giuridici. Milano: Dott A. Giuffrè, 1971.

BARBOSA, Rui. Comentários à Constituição Federal Brasileira. São Paulo: Saraiva/ Livraria Acadêmica, 1933. v. II.

BONAVIDES, Paulo. A Constituição aberta. Belo horizonte: Del Rey, 1993.

BRITTO, Carlos Ayres. Teoria da Constituição. Rio de Janeiro: Forense, 2003.

COSSIO, Carlos. Teoría de la verdad jurídica. Buenos Aires: Losada, 1954.

DABIN, Juan. Théorie générale du droit. Bruxelles: Émile Bruylant, 1944.

DEL VECCHIO, Giorgio. Direito, Estado e filosofia. Tradução de Luis Luiggi. Rio de Janeiro: Politécnica, 1952.

Filosofía del derecho. Edición revisada por Luis Legaz y Lacambra. Barcelona: Bosch, 1960.

. Persona, Estado y derecho. Prólogo de Manuel Fraga Iribarne. Madrid: Instituto de Estudios Políticos, 1957, 
FRANÇA, R. Limongi. Brocardos jurídicos: as regras de Justiniano. Tradução, estudo crítico preliminar e notas de R. Limongi França. São Paulo: Revista dos Tribunais, 1969.

HAESAERT, J. Théorie génerale du droit. Bruxelles: Émile Bruylant; Paris: Librairie du Recueil Sirey, 1948.

HOBBES, Thomas. Elementos do direito natural e político. Tradução de Fernando Couto. Porto: Rés, 1993.

KELSEN, Hans. Problemi fondamentali della dottrina del diritto pubblico. Tradução de Agostino Carrino. Napoli: Edizione Scientifiche Italiane, 1977.

LASSALLE, Ferdinand. Que é uma Constituição? Tradução de Walter Stönner. Rio de Janeiro: Laemmert, 1969.

PALLIERI, Giorgio Balladore. Doutrina do estado. Tradução de Fernando de Miranda. Coimbra: Coimbra Ed., 1969. v. II.

PIMENTA, Paulo Roberto Lyrio. Eficácia e aplicabilidade das normas constitucionais programáticas. São Paulo: Max Limonad, 1999.

SILVA, José Afonso da. Aplicabilidade das normas constitucionais. São Paulo: Malheiros, 1998.

. Curso de direito constitucional positivo. São Paulo: Malheiros, 1993.

STAMMLER, Rudolf. Economía y derecho según la concepción materialista de la historia. Tradução de W. Roces. Madrid: Reus,1929.

TEIXEIRA, José Horácio Meirelles. Curso de direito constitucional. Texto organizado e atualizado por Maria Garcia. Rio de Janeiro: Forense Universitária, 1991.

VASCONCELOS, Arnaldo. Direito e força: uma visão pluridimensional da coação jurídica. São Paulo: Dialética, 2001.

. Teoria da norma jurídica. São Paulo: Malheiros, 2006. 
Teoria pura do direito: repasse crítico de seus principais fundamentos. Rio de Janeiro: GZ Ed., 2010.

Recebido em: 13/11/13

Aprovado em: 12/12/13 